\title{
Latent heat storage in PCM containing mortars-Study of microstructural modifications
}

\author{
S.S. Lucas $^{\mathrm{a}, *}$, V.M. Ferreira ${ }^{\mathrm{a}}$, J.L. Barroso de Aguiar ${ }^{\mathrm{b}}$ \\ a University of Aveiro/CICECO, Department of Civil Engineering, 3810193 Aveiro, Portugal \\ ${ }^{\mathrm{b}}$ University of Minho, Department of Civil Engineering, Campus de Azurém, 4800058 Guimarães, Portugal
}

\section{A R T I C L E I N F O}

\section{Article history:}

Received 17 October 2012

Received in revised form 15 June 2013

Accepted 26 July 2013

\section{Keywords:}

Phase change materials

Microstructure

Mortars

Heat storage

\begin{abstract}
A B S T R A C T
The incorporation of phase change materials (PCM) into traditional mortars give to these products the ability to store and release heat. In this way it is possible to reduce the energy consumption and improve the thermal comfort in buildings. The introduction of micro and nanomaterials in the mortars matrix can cause microstructural changes that need to be addressed in order to optimize the PCM addition. The relationship between the hardened state performance of different PCM-mortars, its internal microstructure and pore distribution as been observed for different binders such as lime, cement and gypsum. Their hardened state properties, microstructural modifications and heat storage capabilities were evaluated. The ability to store and release heat depends strongly on the size and distribution of internal pores and not only on the PCM content. Using a thermal efficiency test, an important correlation between thermal performance and the mortars microstructure was established, for mortars with $0-30 \%$ of PCM added.
\end{abstract}

(c) 2013 Elsevier B.V. All rights reserved.

\section{Introduction}

Planning low energy buildings constitute a major challenge for sustainable construction. Excessive demand on fossil fuels contributes for the depletion of non-renewable resources and higher pollutant emissions. Growth on energy prices result in more operational expenses from heating and cooling systems, increasing the buildings life cycle cost [1]. To perform an energy impact assessment it is essential to consider the total energy consumption during the building life cycle, including the use of heating, cooling and lightning systems. Materials selection can be of particular importance, since it can contribute to a significant reduction of the operational energy intake, improving the building environmental performance [2]. The use of materials with latent heat storage capabilities reduces the HVAC (heating, ventilation, and air conditioning systems) operation time, saves energy, diminish the pollutant emissions and fossil fuels depletion [3]. Latent heat storage occurs at constant temperature with low volume change and PCM (phase change materials) can store high amounts of energy. The latent heat transfer, caused by the PCM fusion, occurs at a temperature designated as phase change temperature. Latent heat

\footnotetext{
* Corresponding author. Tel.: +351933480007.

E-mail addresses: sandra.lucas@ua.pt (S.S. Lucas), victorf@ua.pt (V.M. Ferreira), aguiar@civil.uminho.pt (J.L.B.d. Aguiar).
}

storage is therefore dependent of the enthalpy change and can be determined from Eq. (1).

$\Delta Q=m \times \Delta H$

where $\Delta H$, enthalpy variation (J); and $m$, material mass (g).

One of the first studies concerning thermal energy storage was published in 1947 and describes an attempt of applying PCM in thermoelectric generators [4]. Reports performed by NASA in the 60's and early 70's delivered the first findings on thermal energy storage materials with PCM [5]. Energy crisis and growing environmental concerns motivated the research of possible applications of PCM as an alternative for energy storage in buildings. Phase change materials can be classified into different classes depending on their chemical composition [6]. Organic PCM are amongst the most studied and used, having a wide range of possible applications. Paraffins mixtures are commercially available, with a very competitive price and therefore, interesting for buildings applications [7]. They are available in several transition temperatures, compatible with the construction materials and are chemically stable [3]. In constructive applications - where contamination and leakage might compromise the system efficiency - the PCM required encapsulation. Depending on the size of the capsule, the method can be classified as macro or microencapsulation. The microencapsulation method can produce capsules ranging from $1 \mu \mathrm{m}$ to $1000 \mu \mathrm{m}$ containing small quantities of PCM confined in a shell of a polymer thin film, usually PMMA (polymethylmethacrylate) [8]. The research of potential applications of PCM in mortars has been focused mainly in cement and gypsum compositions. 
Several authors studied the impregnation of concrete, demonstrating the viability of the process for latent heat storage [9]. The reduction of the structural weight compared to the traditional product is one of the main advantages of this technique. In lightweight construction, the lower thermal mass increases the energy demand to maintain the indoor temperature within the comfort range. The incorporation of PCM in light structures, taking advantage of passive solar gains, reduce the temperature peaks and energy intake for heating and cooling [10]. However the impregnation method presents several problems, such as: high risk of leakage to the surface, loss of material integrity, decrease in mechanical strength, odours and poor adhesion of paint coatings to the surface [11]. The development of the microencapsulation technique and its commercial availability enables the incorporation into porous materials. The product became safer, with the leakage problem and odour release solved [12]. Cement products incorporating phase change materials exhibit high thermal performance so they are viable as a construction product [13]. The PCM is introduced in the cement and gypsum pastes as an emulsion, which implies a higher water content causing a mechanical strength reduction [14,15]. In the past years, several commercial products with latent heat storage capabilities (concrete and gypsum wallboards) appeared in the market. Lime mortars are commonly used in the rehabilitation of historic buildings consequently, the incorporation of PCM enhances mortars workability and hardened state properties, increasing energy efficiency $[16,17]$.

This work attempts to establish a relationship between the hardened state performance of different PCM-mortars and its internal microstructure and pore distribution. Several binders such as lime, cement and gypsum, with different PCM contents were used.

\section{Experimental}

\subsection{Materials and formulations}

Different mortars were prepared with three commercial binders: hydrated lime, Portland cement CEM II $32.5 \mathrm{~N}$ and gypsum stucco plaster; siliceous sand was used as fine aggregate. The phase change material (Micronal DS 5008) comprises a paraffin mixture encapsulated in a polymethylmethacrylate (PMMA) shell, with an average particle size of $6 \mu \mathrm{m}$, transition temperature of $23^{\circ} \mathrm{C}$ and enthalpy of $135 \mathrm{~kJ} / \mathrm{kg}$. It was added to the mixtures $1 \mathrm{wt} . \%$ of a superplasticizer (Glenium 51), for workability control. According to Table 1 , a pre-defined set of base compositions were tested with different PCM amounts (0,10, 20 and 30 wt.\% of total solids). The kneading water content was adjusted to each formulation in order to maintain the slump value constant (Table 2 ), keeping the mortar

Table 1

Compositions of the PCM-mortars (wt.\%).

\begin{tabular}{llrrrr}
\hline \multicolumn{2}{l}{ Composition } & $0 \%$ PCM & $10 \%$ PCM & $20 \%$ PCM & $30 \%$ PCM \\
\hline L & Lime & 25 & 23 & 21 & 19 \\
& Sand & 75 & 68 & 63 & 58 \\
& PCM & 0 & 9 & 17 & 23 \\
LC & Lime & 9 & 8 & 8 & 7 \\
& Cement & 13 & 12 & 11 & 10 \\
& Sand & 78 & 71 & 65 & 60 \\
& PCM & 0 & 9 & 17 & 23 \\
LG & Lime & 12 & 11 & 10 & 9 \\
& Gypsum & 8 & 7 & 7 & 6 \\
& Sand & 80 & 73 & 67 & 62 \\
& PCM & 0 & 9 & 17 & 23 \\
& Cement & 20 & 18 & 17 & 15 \\
& Sand & 80 & 73 & 67 & 62 \\
& PCM & 0 & 9 & 17 & 23 \\
\hline
\end{tabular}

Table 2

Water content, flow value and density for the fresh compositions tested.

\begin{tabular}{lclll}
\hline Composition & \% PCM & Water (wt.\%) & Flow value $(\mathrm{mm})$ & Fresh density $\left(\mathrm{g} / \mathrm{cm}^{3}\right)$ \\
\hline L & 0 & 25 & 150 & 2.0 \\
& 10 & 27 & 150 & 1.6 \\
& 20 & 30 & 150 & 1.5 \\
& 30 & 33 & 150 & 1.5 \\
LC & 0 & 17 & 150 & 1.7 \\
& 10 & 19 & 150 & 1.7 \\
& 20 & 21 & 150 & 1.7 \\
& 30 & 29 & 150 & 1.7 \\
LG & 0 & 17 & 170 & 2.0 \\
& 10 & 22 & 170 & 1.8 \\
& 20 & 26 & 170 & 1.6 \\
& 30 & 30 & 170 & 1.5 \\
C & 0 & 16 & 150 & 1.7 \\
& 10 & 20 & 150 & 1.7 \\
& 20 & 21 & 150 & 1.7 \\
\hline
\end{tabular}

workability as constant as possible with the increasing amount of additive. Slump was determined with the flow table test as specified by European Standard EN 1015-3. The fresh mortars preparation started with the weighting of the raw materials and additives, followed by a manual dry mixing in a plastic bag. The superplasticizer and the kneading water where added and the mortar was mixed in an automatic mixer at $60 \mathrm{rpm}$.

\subsection{Hardened state characterization}

The samples for the mechanical strength tests were prepared following the procedure described in the European Standard EN 1015-11. The tests were carried out after a 90 days curing time, where the samples were stored at a temperature of $20^{\circ} \mathrm{C} \pm 2{ }^{\circ} \mathrm{C}$ and $65 \% \pm 5 \%$ of relative humidity. The pore size and pore distribution was determined using a mercury intrusion porosimeter (AutoPore IV Micromeritics) working in a pressure range from $4 \mathrm{kPa}$ to $228 \mathrm{MPa}$ allowing measuring pores between $5 \mathrm{~nm}$ and $360 \mu \mathrm{m}$. Three samples were prepared for each test and each composition. The PCM and the mortars microstructure were investigated using a scanning electron microscope (SEM) Hitachi SEM SU-70.

\subsection{Thermal efficiency measurements}

The PCM-mortars latent heat storage evaluations were performed with tests that simulate as closely as possible the real application conditions. For this purpose small-scale test cells made with an insulating material (extruded polystyrene) were developed. These cells were built with polysterene board of $10 \mathrm{~mm}$ thickness and have a dimension of $200 \mathrm{~mm} \times 200 \mathrm{~mm} \times 200 \mathrm{~mm}$. The removable top were prepared with styrofoam with an opening for the thermocouples. The cells were coated on the inside with a mortar layer of $3 \mathrm{~mm}$. For each composition, cells with different amounts of PCM (0, 20 and 30 wt.\%) were tested. The thermocouples were placed inside for temperature measurement and were connected to a data acquisition system (Data Logger Switch Unit from Agilent). For the climatic chamber tests a temperature cycle was set a minimum temperature of $10^{\circ} \mathrm{C}$ and maximum of $40^{\circ} \mathrm{C}$ with a heating and cooling rate of $0.5^{\circ} \mathrm{C} / \mathrm{min}$. There was a steadystate period of $10 \mathrm{~min}$ at the maximum and minimum temperature value. The aim is to trigger the PCM phase transition (between 23 and $25^{\circ} \mathrm{C}$ ) to assess the impact of the heat storage and release when the temperature rises or falls throughout the cycle. 


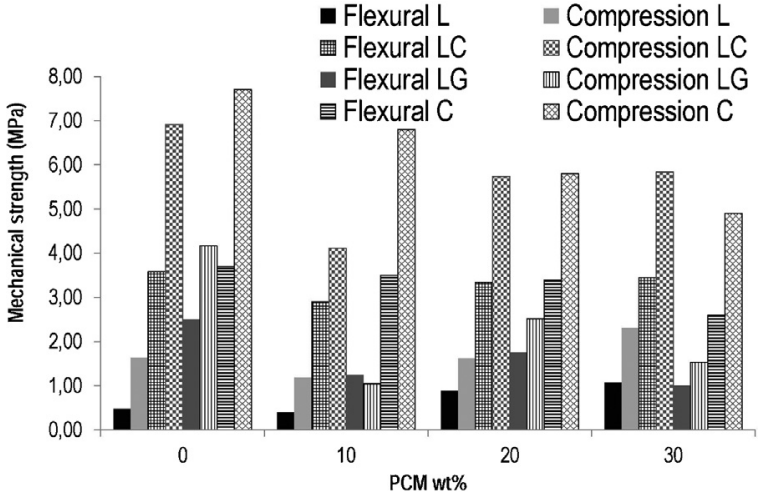

Fig. 1. Mechanical strength of the mortar compositions tested.

\section{Results and discussion}

\subsection{Hardened state properties}

Fig. 1 shows the results of the flexural and compression strength for the all the compositions.

For the lime composition (L), with $10 \mathrm{wt} . \%$ of PCM, the mechanical strength remained stable, showing only a slight reduction however, with 20 and 30 wt.\% of PCM increases, even surpassing the value of the reference mortar ( $0 \mathrm{wt}$ \% PCM). These results, obtained with the aerial lime mortars are different from what is stated in other studies, where concrete and plaster are incorporation matrix for the PCM $[14,15]$. Hunger et al. reported a mechanical strength loss of $30 \%$ in cement mortars for an addition of only $1 \mathrm{wt} . \%$ of PCM, with $5 \mathrm{wt} . \%$ the reduction is higher than $60 \%$. Therefore, an analysis of microstructure and porosity distribution is essential to understand the hardened state behaviour of the lime mortar composition. The differences in the mechanical strength obtained for the tested compositions could be related with the internal porosity and pore size distribution of the mortar.

Fig. 2 shows the curves that represent the internal porosity distribution, for each lime formulation tested. Without PCM the pores distribution is bimodal, having clearly defined dimension ranges (around $0.75 \mu \mathrm{m}$ and $12 \mu \mathrm{m}$ ), but with the incorporation of PCM the pore size decreases. The reduction of the macroporosity (above $5 \mu \mathrm{m}$ ) and a larger concentration of nanopores (below $0.5 \mu \mathrm{m}$ ), for $20 \mathrm{wt} . \%$ and $30 \mathrm{wt} . \%$ of PCM, can be the reason for the mechanical strength increase. The PCM incorporation results in a better pore size distribution inside the lime mortar matrix, contributing to an improvement of the mechanical properties. Other authors also found that, in aerial lime mortars, the hardened state performance is strongly influenced by the pores dimension and concluded that the mortars with smallest ones exhibit higher mechanical

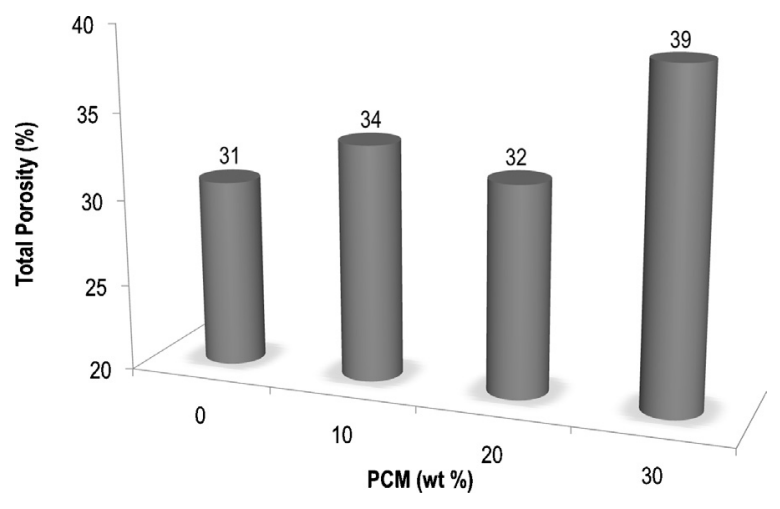

Fig. 3. Total porosity of the lime mortars.

strength [18]. Up to $20 \mathrm{wt} . \%$ of PCM, the increasing amount of pores, being more meaningful for the ones smaller than $1 \mu \mathrm{m}$, stabilizes the total porosity (Fig. 3). In the mortar with $30 \mathrm{wt} . \%$, the total porosity increases as a consequence of the presence of micropores $0.5-5 \mu \mathrm{m}$ ) however does not affect the mechanical properties. It can be concluded that the pore size reduction, overlaps the porosity increase, contributing to enhance the hardened state performance. This clearly demonstrates the impact of the pore size reduction to the mechanical strength improvement of aerial lime mortars [19].

In the lime-cement mortar (LC), 50\% of air lime binder was replaced by cement. According to Fig. 1, the use of cement obviously leads to higher mechanical strength compared to the plain air lime mortar. Even with the increasing content of PCM, the values remain above $2.5 \mathrm{MPa}$ (flexural) and $4 \mathrm{MPa}$ (compression). The reduction of the mechanical strength with the addition of $10 \mathrm{wt} . \%$ of PCM and the subsequent increase is similar to what was observed in the air lime composition (L). In Fig. 4, it can be seen that the reference mortar also presents a bimodal porosity distribution. The presence of cement as binder can help to reduce the volume of pores and total porosity [20]. The incorporation of PCM implies a gradual reduction of the larger pores (above $1 \mu \mathrm{m}$ ) that leads the pore distribution curve to progressively move to a range below $1 \mu \mathrm{m}$ with $10 \mathrm{wt} . \%$ of PCM and $0.5 \mu \mathrm{m}$ for 20 and $30 \mathrm{wt} . \%$ of additive content. It can be concluded that the mechanical strength is more affected by the size of the pores than for the total porosity (Fig. 5), in other words, by reducing the average pore size it is possible to increase the mechanical strength [21]. Introducing cement reduces the pore size when compared to the lime composition (L), for equal amounts of PCM. Arandigoyen et al. report benefits of using blended cementlime mortars in rehabilitation work, stating that it is advantageous and does not compromise in many cases the compatibility with pre-existing materials [22]

Fig. 1 shows that for the mechanical strength of the composition identified as LG, a mortar composed by two binders - lime and

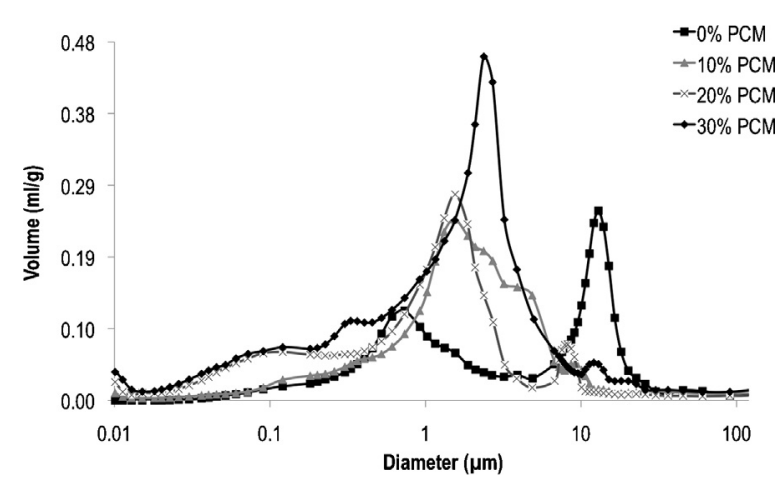

Fig. 2. Pore size distribution of the lime mortars.

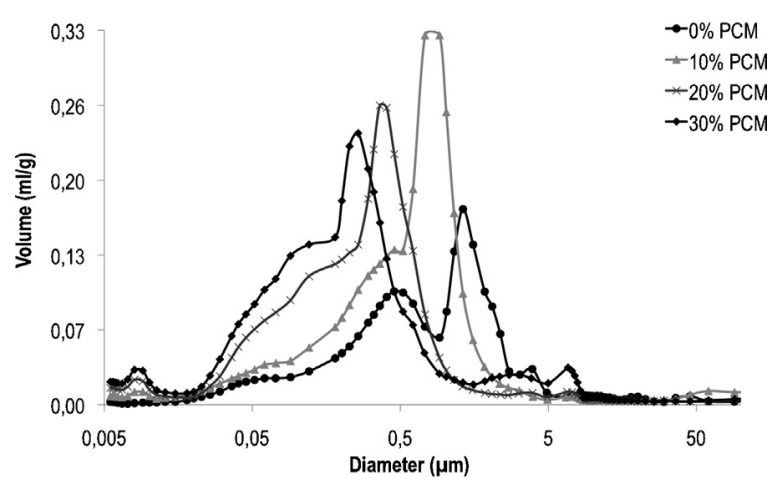

Fig. 4. Pore size distribution of the lime-cement mortars. 


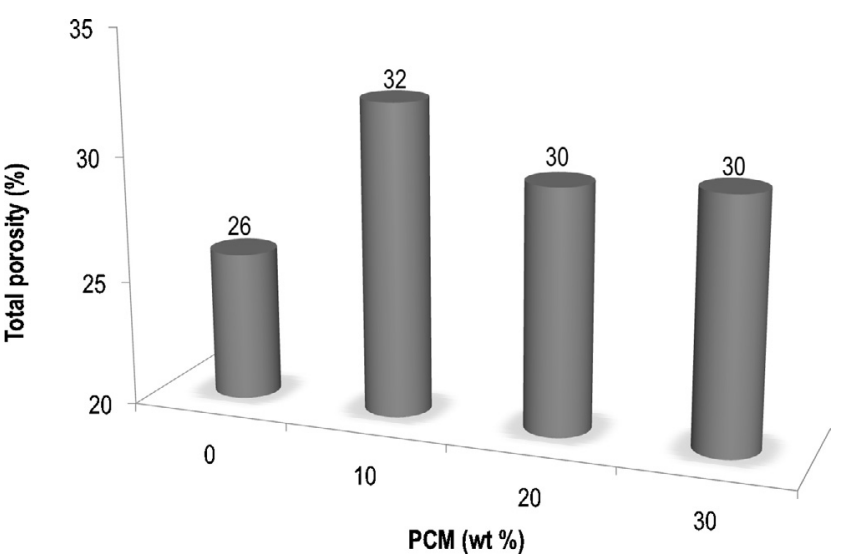

Fig. 5. Total porosity of the lime-cement mortars.

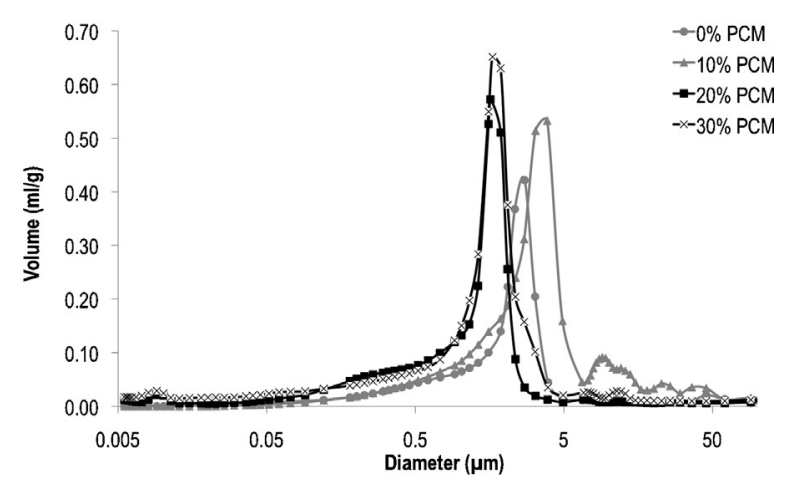

Fig. 6. Pore size distribution of the lime-gypsum mortars.

gypsum, with the increasing PCM content, is different from the previous compositions ( $\mathrm{L}$ and $\mathrm{LC}$ ). The values obtained with PCM are always lower than the reference mortar - the recovery noticed in $\mathrm{L}$ and LC compositions does not take place. The introduction of gypsum in the base composition has dramatically changed the porosity distribution (Fig. 6), which concentrates on higher values, close to $2.5 \mu \mathrm{m}$, with some residual porosity in the range between 7 and $15 \mu \mathrm{m}$. Even with the elimination of the larger pores (above $7 \mu \mathrm{m}$ ) with the introduction of PCM, the pores are always distributed in a range between $1 \mu \mathrm{m}$ and $5 \mu \mathrm{m}$, with absence of nanoporosity. The total porosity of the compositions tested is strongly dependent of the pore distribution curves, as shown in Fig. 7. The $20 \mathrm{wt} . \%$ formulation having lower pore size and lower porosity, exhibit higher mechanical strength.

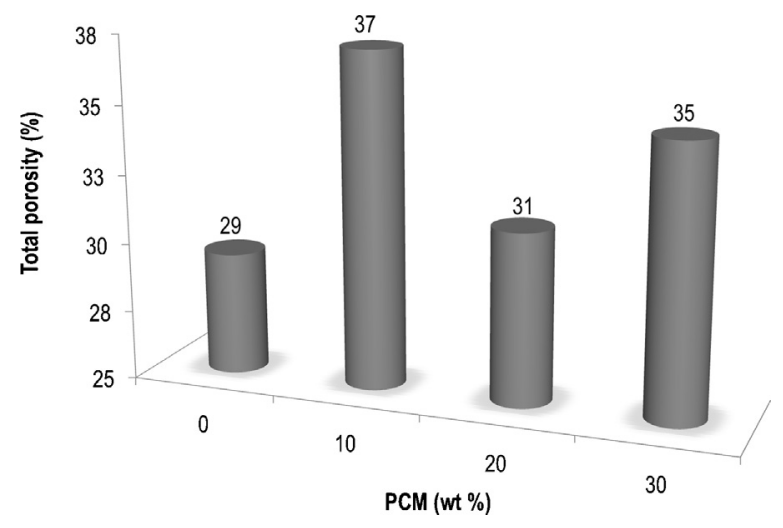

Fig. 7. Total porosity of the lime-gypsum mortars.

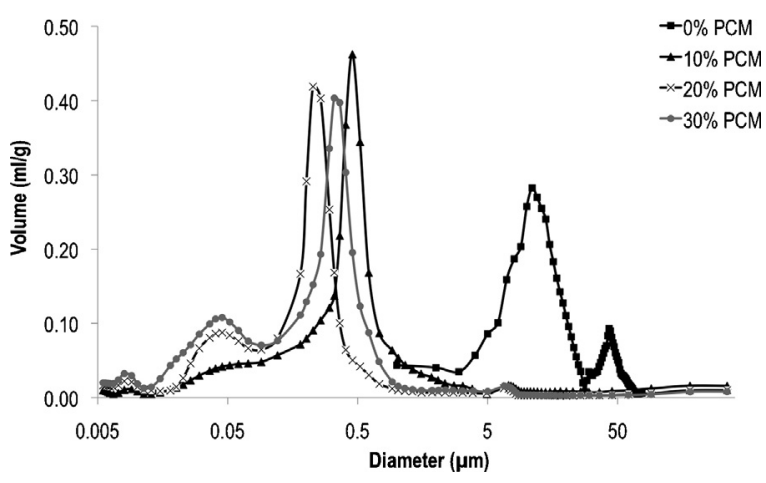

Fig. 8. Pore size distribution of the cement mortars.

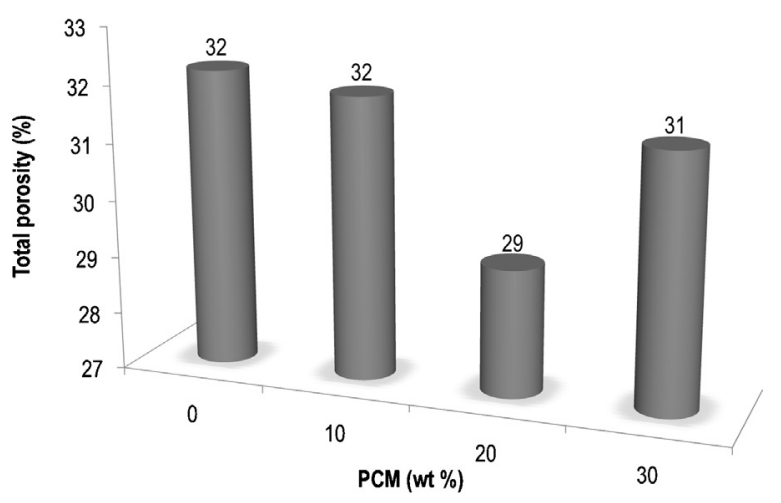

Fig. 9. Total porosity of the cement mortars.

Although being less apparent the benefit of the lime binder in the lime-gypsum mortar, it can be concluded that aerial lime contributes to reduce the macroporosity in PCM-containing mortars, which explains the improved mechanical strength. In the lime and the lime-cement compositions ( $\mathrm{L}$ and LC), the significant growth of nanoporosity caused by the PCM incorporation, increases the mechanical strength.

For the cement mortar (C), there is a steady mechanical strength decrease with the increase of PCM added (Fig. 1) although, even for $30 \mathrm{wt}$.\% of PCM, the compressive strength exceeds $4 \mathrm{MPa}$. The formulation without PCM exhibits internal porosity distributed in two distinct intervals (Fig. 8), between 10 and $100 \mu \mathrm{m}$ and $0.05-4 \mu \mathrm{m}$. With the incorporation of PCM into the cementitious matrix, the distribution curve moves to smaller sizes with a filling effect that eliminates the macropores. The difference of the cement mortar (C) to the lime (L) and lime-cement (LC) compositions lies in the pores size, which is, in this case above $0.5 \mu \mathrm{m}$. Nevertheless, it is possible to incorporate the microcapsules of PCM (with average size between 1 and $10 \mu \mathrm{m}$ ) in the cement mortar matrix, without compromising the hardened state properties [23]. The filing effect of the larger pores, that were present in great extent in the reference mortars ( $0 \mathrm{wt} . \% \mathrm{PCM}$ ), causes a slight decrease of the bulk porosity in the composition with $20 \%$ of PCM (Fig. 9). In the composition with $30 \mathrm{wt} . \%$ of additive, the porosity above $0.2 \mu \mathrm{m}$ increases as well as total porosity, which reduces the mechanical strength.

\subsection{Microstructure}

By a more detailed analysis of the PCM in a scanning electron microscope (SEM), it was concluded that these particles - with dimensions between 3 and $20 \mu \mathrm{m}$ (Fig. 10) - are in fact aggregates consisting of smaller spherical particles. In the Fig. 10 its included an image taken with greater magnification of individual particles of PCM smaller than $1 \mu \mathrm{m}$. An analysis of these images helped 


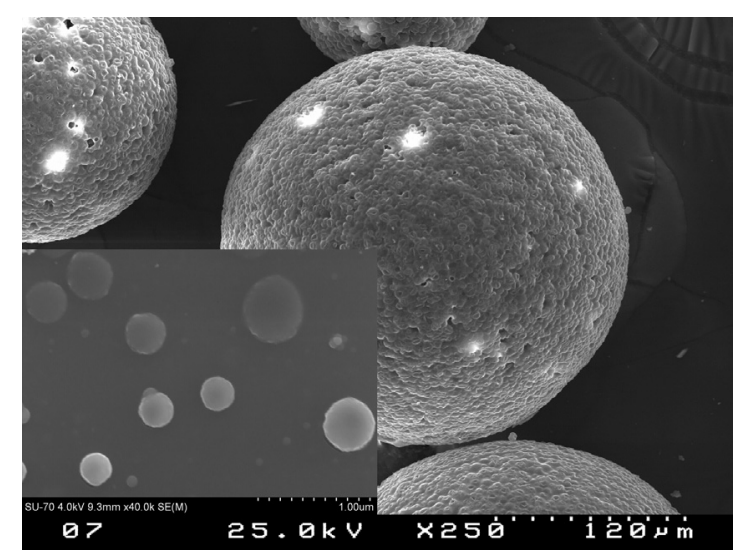

Fig. 10. PCM capsules aggregates (Micronal ${ }^{\circledR}$ DS5008) with magnified view of the PCM nanoparticles.

to determine an average size of $0.4 \mu \mathrm{m}$ for the capsules. So, even though the current designation of microcapsules, it can be consider a nanomaterial. The spherical shape of the capsules and its aggregates contributes to reduce the inter-particles friction and favours the lime mortars workability. The incorporation of PCM facilitates the mixing process in lime mortars, allowing a good control of fresh properties and a better hardened state performance [17].

SEM (Figs. 11 and 12), show the internal structure of the limebased compositions with $30 \mathrm{wt} . \%$ of PCM ( $\mathrm{L}$ and LC). It can be seen that the way the capsules are distributed in the mortar matrix contributes to reduce the pores size. The internal structure of the mortar with PCM is more cohesive in comparison with the

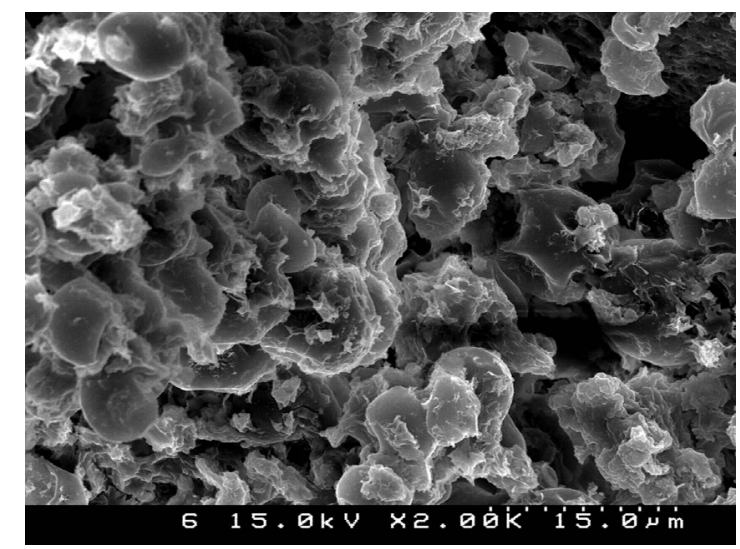

Fig. 11. Microstructure of the lime-cement mortar with 30 wt.\% of PCM.

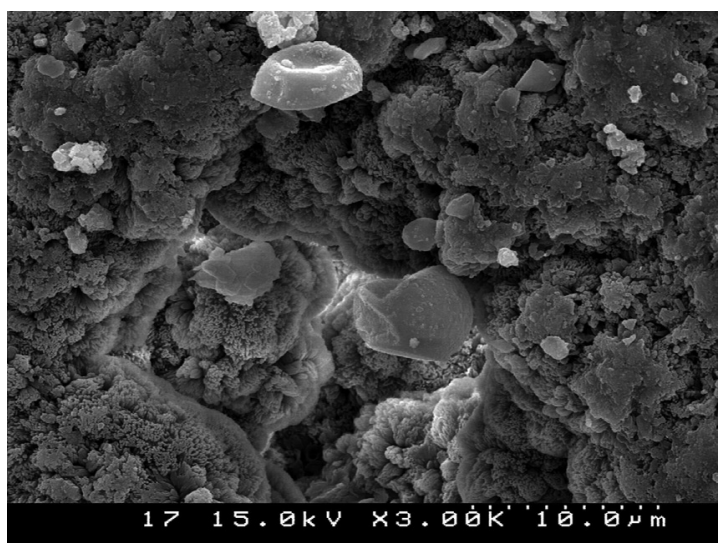

Fig. 12. Microstructure of the lime-gypsum mortar with 30 wt.\% of PCM.

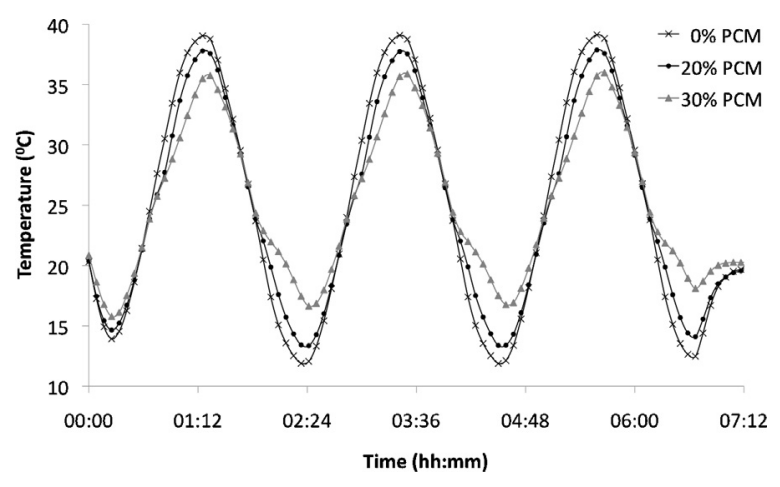

Fig. 13. Temperature evolution in the test cells for the lime mortar.

reference mortar that exhibits biggest pores. The PCM shows a good integrity, without signs of rupture or damages, which demonstrates that the microcapsules can resist the process of the mortar preparation (mixing, application and curing).

\subsection{Latent heat storage performance}

The air lime mortar (L) was tested in a climatic chamber and Fig. 13 demonstrates the effect of PCM when incorporated into the base formulation. This effect is more evident in the composition with 30 wt.\% of PCM, but even with 20 wt.\% is already visible the latent heat storage capability. The curves of $20 \mathrm{wt} . \%$ and $30 \mathrm{wt} . \%$ show a delay relative to the reference one. With the addition of PCM, the test cells take longer to reach the maximum and minimum temperature, during heating and cooling respectively.

it is observed that as the temperature leaves the interval between the $20^{\circ} \mathrm{C}$ and $25^{\circ} \mathrm{C}$ (the PCM phase change) the curves of the test cells with additive begin to evolve differently from the reference cell. During the heating process, when the imposed temperature exceeds $25^{\circ} \mathrm{C}$, the test cells with PCM exhibited a slower heating rate. The reference cell have the highest temperature, in the cells with PCM, the maximum temperature is lower. The same effect can be verified in the cooling stage, more pronounced in the cell with $30 \mathrm{wt} . \%$. When the temperature lies near the indoor thermal comfort zone, the cells exhibit similar temperature values, since the PCM does not react within this range. The effect of latent heat storage (heating) and heat release (cooling) is detected only when the temperature diverges from the thermal comfort zone. The lower heating and cooling rate validated by the test cells with 20 and 30 wt.\% of PCM confirm the heat storage capability. Since cells with PCM did not reach such extreme temperatures as the reference test cell, the temperature inside remains stable for a longer period. This mean a shortest operation time of HVAC systems when PCM-mortars are used and effective energy saving can be achieved. The analysis of the temperature evolution curves does not provide enough information about the behaviour of these mortars when subject to consecutive heating and cooling cycles. It is necessary to assess how the temperature differs within each cell, relative to the reference one. Fig. 14 shows the variation of the thermal gradient throughout the test. This gradient reflects the temperature difference between the cell with PCM-mortar and the reference cell. It is determined by the difference between the cell test with PCM and the reference cell, in each moment of the temperature cycle. Thus, at any given moment, $i$, the temperature gradient between the reference cell and the cell with PCM can be calculated by the formula from Eq. (2):

$\Delta T_{t=i}=\left(T_{\mathrm{ref}}-T_{\mathrm{PCM}}\right)_{t=i}$

where $T_{\text {ref }}$, reference temperature at instant $t=i\left({ }^{\circ} \mathrm{C}\right)$; and $T_{\mathrm{PCM}}$, temperature inside the cell with PCM when $t=i\left({ }^{\circ} \mathrm{C}\right)$. 


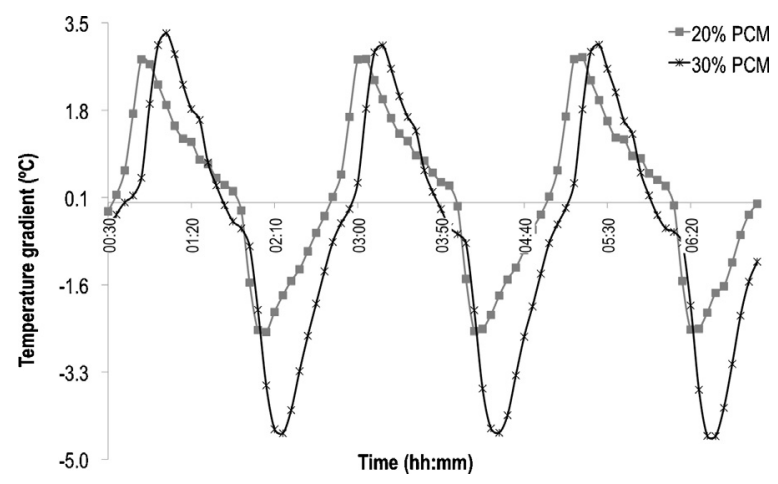

Fig. 14. Temperature gradient in the test cells for the lime mortar.

As the temperature cycle runs, the thermal gradient in cells with PCM increases - as a result of the cyclic heat storage process. Hence, the gradient decreases until it reaches the point where the cells are all with the same temperature. This point is reached in the zone between 23 and $25^{\circ} \mathrm{C}$, the thermal comfort zone (Fig. 14). The mortar with $30 \mathrm{wt} . \%$ of PCM - which presents pores between 1 and $5 \mu \mathrm{m}$ and a higher value of total porosity - exhibits the largest thermal gradient. With $20 \mathrm{wt}$.\% of PCM the porosity distribution lies between 0.4 and $3 \mu \mathrm{m}$ so, because average pores size is smaller and the porosity lower, the heat transfer is delayed. The pore distribution play an important role in the heat exchange between the PCM and air - the reduction in the pores size can difficult such transfer. Since the heat exchange is slower than in composition with $30 \mathrm{wt} . \%$ of PCM, there is a reduction of the thermal gradient. Although the smaller thermal gradient in the cell with $20 \mathrm{wt}$.\% PCM, particularly during cooling, it is possible to achieve differences exceeding $2{ }^{\circ} \mathrm{C}$ - allowing to obtain energy savings with the application. The fact that the lime mortars have higher amount of pores below $0.5 \mu \mathrm{m}$, confirmed with the mercury intrusion porosimetry, has delayed the heat exchange.

For the lime-cement mortar (LC), the behaviour is opposite to the observed in with the lime composition, L (Fig. 15). Now, the most significant difference between the heating and cooling curves can be seen for the mortar with $20 \mathrm{wt}$.\%. It shows a delay in the heating and cooling rate and the temperature range is narrower. During the heating process, shortly after the phase change at $26^{\circ} \mathrm{C}$, the temperature curve for the cell with $20 \mathrm{wt} . \%$ of additive stands out, while for the mortar with $30 \mathrm{wt} . \%$, the difference only became noticeable for $35^{\circ} \mathrm{C}$. The difference in the temperature evolution throughout the cycle is even more apparent during the cooling process. With $20 \mathrm{wt}$.\% of PCM the decrease in the cooling rate begins at $23^{\circ} \mathrm{C}$, to $30 \mathrm{wt}$.\% of additive only starts below $17^{\circ} \mathrm{C}$. Fig. 16 shows the variation of the thermal gradient, which is more pronounced in the cell with $20 \mathrm{wt}$.\% of PCM. It should be expected that the

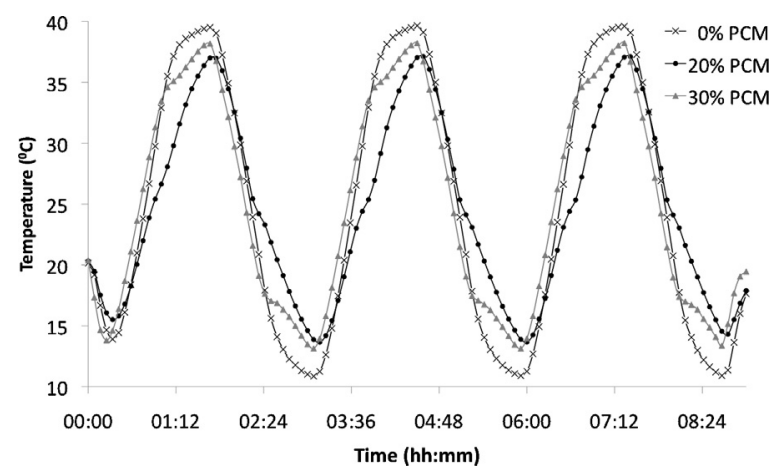

Fig. 15. Temperature evolution in the test cells for the lime-cement mortar.

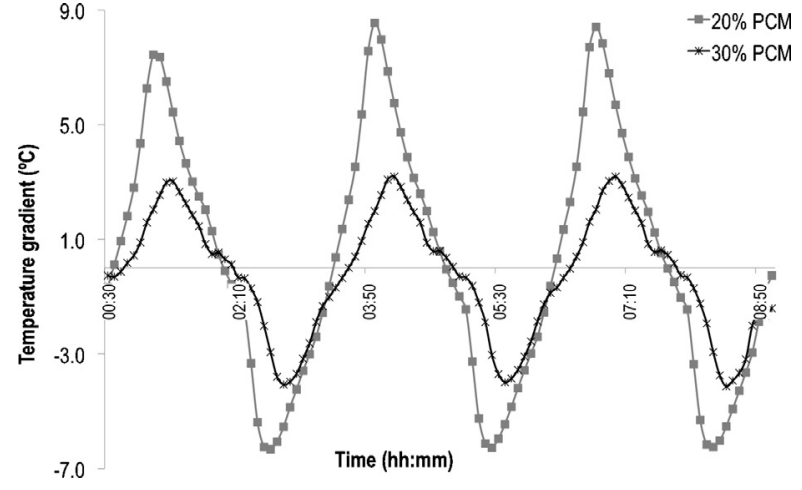

Fig. 16. Temperature gradient in the test cells for the lime-cement mortar.

composition with more PCM exhibit the highest thermal gradient however, the porosity plays a key role in the heat transfer from the PCM-mortar to the air inside the cell. The porosity distribution for the mortar with $20 \mathrm{wt}$.\% lies in the range of $1 \mu \mathrm{m}$ and for the composition with $30 \mathrm{wt} . \%$ there is an increase in nanoporosity (pores below $0.5 \mu \mathrm{m}$ ). Even with similar porosity distribution for both compositions, the reduction of pores size difficult the heat transfer, even with higher PCM content.

The lime-gypsum mortar (LG) shows a behaviour similar to the one presented by the lime mortar $(\mathrm{L})$, however the difference between the reference cell and the 20 and $30 \mathrm{wt}$.\% curves is more pronounced and in this case the $30 \mathrm{wt}$.\% has a better performance (Fig. 17). With this composition a better efficiency is achieved during cooling, with differences between 2 and $5{ }^{\circ} \mathrm{C}$. The temperature gradient is higher to the composition with $30 \mathrm{wt}$ \% (Fig. 18). For $20 \mathrm{wt} . \%$ of PCM, with a porosity distributed by a narrower range, $0.7-3 \mu \mathrm{m}$, the heat release is extended in time. For the composition with $30 \mathrm{wt} . \%$ there is an increase of pores with $3-4 \mu \mathrm{m}$, so the heat

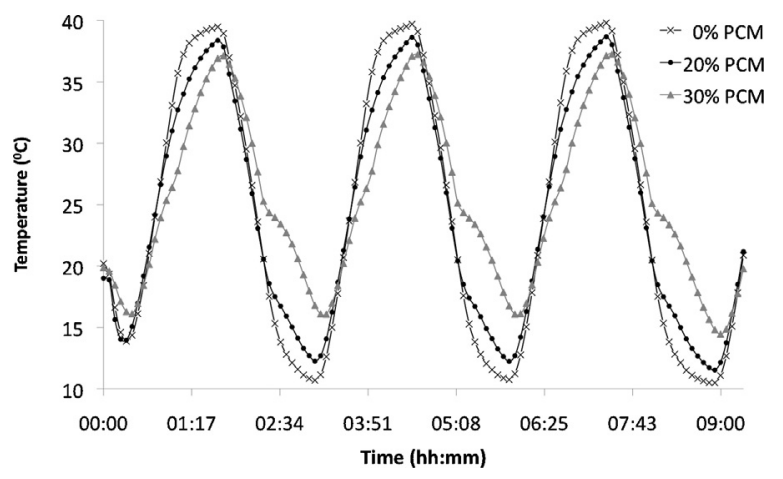

Fig. 17. Temperature evolution in the test cells for the lime-gypsum mortar.

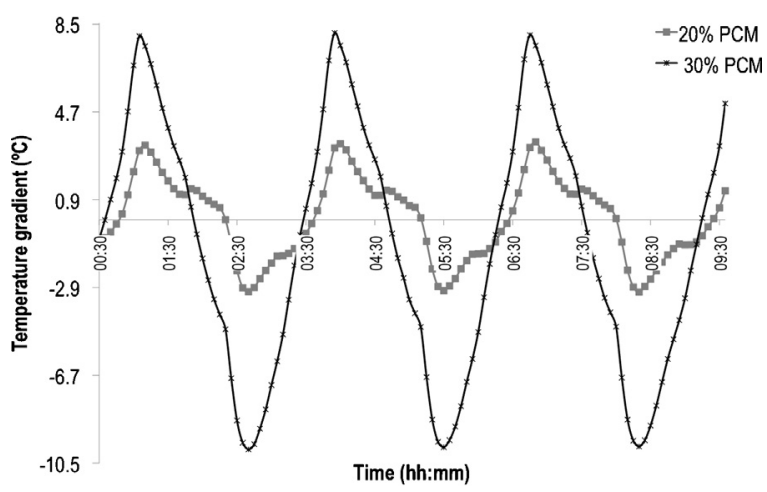

Fig. 18. Temperature gradient in the test cells for the lime-gypsum mortar. 


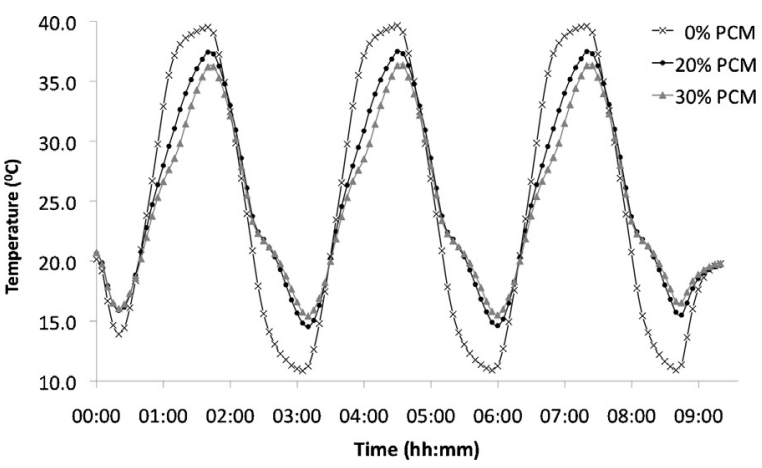

Fig. 19. Temperature evolution in the test cells for the cement mortar.

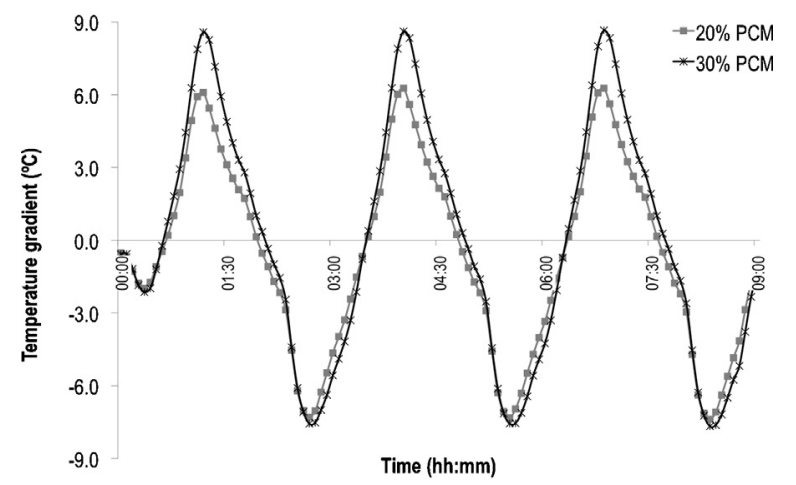

Fig. 20. Temperature gradient in the test cells for the cement mortar.

transfer is enhanced. This effect is possible to observe in the thermal gradient curve, which shows how quickly heat is transferred to the air inside the cell.

The cement composition (C) is the one with minor differences for the different amounts of PCM added. The curves follow a very similar pattern in both heating and cooling, as can be seen in Fig. 19. The porosity distribution to this mortar - with 20 and $30 \mathrm{wt} . \%$ of PCM - is identical, and the pore average size variation is much smaller, which resulted in two very similar thermal gradient curves (Fig. 20). The cement mortar with 30 wt.\% of PCM has a thermal gradient slightly higher since the porosity is greater than that in the mortar with 20 wt.\%.

\section{Conclusions}

The effect of the incorporation of functional additives in mortars for inner wall coating was studied. The introduction of a phase change material (PCM) was assessed for mortars prepared with different binders - lime, cement and gypsum. The PCM selected is composed by spherical aggregates with an average size of $6 \mu \mathrm{m}$. However, SEM analysis proved that smaller capsules with $0.4 \mu \mathrm{m}$ form this aggregates, which can be classified as a nanomaterial.

There was a strong reduction of macroporosity for the lime and lime-cement mortars, which led to an increase of the mechanical strength, in compositions with $20 \mathrm{wt}$.\% and $30 \mathrm{wt}$.\% of PCM. The mechanical strength evolution can be directly associated to the presence of nanoporosity that contributes to increase its values, even when the amount of pores is higher. The cement mortar shows a reduction in mechanical strength with increasing contents of PCM. Filling the larger pores counterbalances the detrimental effect of introducing a nanoadditive with a high specific surface area into the mortars. However, contrary to lime based mortars, in cement compositions the nanopores content is not enough to improve the mechanical strength for increasing amounts of PCM. It can be stated that the different mortars compositions tested have shown good mechanical performance, with 20 and $30 \mathrm{wt} . \%$ of PCM added, allowing its application as a wall coating.

The mortars were evaluated for their latent heat storage capabilities using test cells developed specifically for these experiments. The cells were placed inside a climatic chamber and subjected to a temperature cycle varying from $10^{\circ} \mathrm{C}$ to $40^{\circ} \mathrm{C}$. These tests helped to determine the extent of the attenuation effect during heating and cooling, with the incorporation of the PCM nanocapsules. The mixtures with 20 and 30 wt.\% of PCM have a higher thermal gradient compared to the reference mortar. It was demonstrated that a higher PCM content does not necessarily implies an increase in the latent heat transfer, proving that the internal porosity plays a very important role in this process. The presence of nanopores reduces the heat transfer capability even when the PCM content is higher. From this study it is possible to fix the amount of $20 \mathrm{wt} . \%$ of PCM as a good compromise between mechanical performance, thermal efficiency and cost of the solution.

Reducing the energy demand decreases the fossil fuel depletion and the environmental impact associated to the heating and cooling systems. The use of PCM mortars proved to be an efficient strategy to develop sustainable buildings.

\section{Acknowledgement}

The authors acknowledge the Foundation for Science and Technology (FCT) for the financial support (PTDC/ECM/72104/2006).

\section{References}

[1] G.A. Blengini, T. Di Carlo, The changing role of life cycle phases, subsystems and materials in the LCA of low energy buildings, Energy and Buildings 42 (6) (2010) 869-880

[2] S. Lucas, V.M. Ferreira, Selecting insulating building materials trough an assessment tool, in: CIB (Ed.), Portugal SB10 Sustainable Building Affordable to All, Vilamoura, 2010

[3] L.F. Cabeza, A Castell, C. Barreneche, A de Gracia, A.I. Fern.ndez, Materials used as PCM in thermal energy storage in buildings: a review, Renewable and Sustainable Energy Reviews 15 (3)(2011) 1675-1695.

[4] M. Telkes, The efficiency of thermoelectric generators, Journal of Applied Physics 18 (12) (1947) 1116-1127.

[5] E.W. Bentilla, L.E. Karre, R.F. Sterrett, Research and Development Study on Thermal Control by Use of Fusible Materials, NASA, Hawthorne, United States of America, 1966.

[6] R. Baetens, B.r.P. Jelle, A. Gustavsen, Phase change materials for building applications: a state-of-the-art review, Energy and Buildings 42 (9) (2010) 1361-1368.

[7] K. Cho, S.H. Choi, Thermal characteristics of paraffin in a spherical capsule during freezing and melting processes, International Journal of Heat and Mass Transfer 43 (17) (2000) 3183-3196.

[8] A. Loxley, B. Vincent, Preparation of poly(methylmethacrylate) microcapsules with liquid cores, Journal of Colloid and Interface Science 208 (1) (1998) 49-62.

[9] D.P. Bentz, R. Turpin, Potential applications of phase change materials in concrete technology, Cement \& Concrete Composites 29 (7) (2007) 527-532.

[10] M. Xiao, B. Feng, K. Gong, Preparation and performance of shape stabilized phase change thermal storage materials with high thermal conductivity, Energy Conversion and Management 43 (1) (2002) 103-108.

[11] A. Pasupathy, L. Athanasius, R. Velraj, R.V. Seeniraj, Experimental investigation and numerical simulation analysis on the thermal performance of a building roof incorporating phase change material (PCM) for thermal management, Applied Thermal Engineering 28 (5/6) (2008) 556-565.

[12] B. Boh, B. Šumiga, Microencapsulation technology and its applications in building construction materials, RMZ - Materials and Geoenvironment 55 (3)(2008) 329-344.

[13] L.F. Cabeza, C. Castellon, M. Nogues, M. Medrano, R. Leppers, O. Zubillaga, Use of microencapsulated PCM in concrete walls for energy savings, Energy and Buildings 39 (2) (2007) 113-119.

[14] M. Hunger, A.G. Entrop, I. Mandilaras, H.J.H. Brouwers, M. Founti, The behavior of self-compacting concrete containing micro-encapsulated phase change materials, Cement \& Concrete Composites 31 (10) (2009) 731-743.

[15] N. Silva, Properties of gypsum-PCM based mortars for interior plastering of construction systems, Materials Science Forum 744 (587) (2008) 913.

[16] S. Lucas, V.M. Ferreira, J.L.B. de Aguiar, J.A. Labrincha, Rehabilitation mortars for zero-impact buildings, in: Conference Proceedings Sustainable 
Building Towards 0-impact Buildings and Environments (SB10), Maastricht, 2010.

[17] S. Lucas, L. Senff, V.M. Ferreira, J.L.B. de Aguiar, J.A. Labrincha, Fresh state characterization of lime mortars with PCM additions, Applied Rheology 20 (6) (2010) 63162.

[18] K. Beck, M. Al-Mukhtar, Formulation and characterization of an appropriate lime-based mortar for use with a porous limestone, Environmental Geology 56 (3/4) (2008) 715-727.

[19] P.J.P. Gleize, A. Mullier, H.R. Roman, Microstructural investigation of a silica fume-cement-lime mortar, Cement \& Concrete Composites 25 (2) (2003) $171-175$.
[20] M.J. Mosquera, B. Silva, B. Prieto, E. Ruiz-Herrera, Addition of cement to limebased mortars: effect on pore structure and vapor transport, Cement and Concrete Research 36 (9) (2006) 1635-1642.

[21] M. Arandigoyen, J.I. Alvarez, Pore structure and mechanical properties of cement-lime mortars, Cement and Concrete Research 37 (5) (2007) $767-775$.

[22] M. Arandigoyen, J.I. Alvarez, Blended pastes of cement and lime: pore structure and capillary porosity, Applied Surface Science 252 (23) (2006) 8077-8085.

[23] A.B. Abell, K.L. Willis, D.A. Lange, Mercury intrusion porosimetry and image analysis of cement-based materials, Journal of Colloid and Interface Science 211 (1) (1999) 39-44. 